\title{
MONISÄRMÄINEN ELOKUVA- JA MEDIATUTKIMUS
}

Mitä elokuva- ja mediatutkimuksessa tapahtuu juuri nyt? Siitä pääset jyvälle uusimman Lähikuva-lehden myötä. Kaksoisnumeron artikkelit tarjoavat laajan katsauksen siihen, mitä kaikkea elokuva- ja mediatutkimuksen alalla tutkitaan Suomessa tällä hetkellä.

Lähikuvaa on toimitettu jo pitkään pääasiassa teema-ajattelun pohjalta. Viime aikoina lehdelle on kuitenkin tarjottu niin runsaasti tekstejä teemojen ulkopuolelta, että päätimme koota niistä teemavapaan numeron. Olemme toimituskunnassa todella iloisia siitä, että meille tarjotaan näin monenlaisia tekstejä elokuva- ja mediatutkimuksen laajalta kentältä.

Käsillä olevasta numerosta käy hyvin selväksi, että Lähikuva on monia eri tieteenaloja edustavien tutkijoiden yhteinen foorumi, aidosti monitieteinen tiedejulkaisu. Kirjoittajien joukossa on ainakin historian, taidehistorian, kulttuurihistorian, kirjallisuuden, taiteen, musiikin ja viestinnän tutkijoita. Elokuva- ja mediatutkimus on lähtökohtaisesti monitieteistä, ja nykyisin esimerkiksi sosiaalisen median tutkimuksen myötä ala laajenee entisestään. Kun muutama vuosikymmen sitten tutkittiin katsojan ja elokuvan vuorovaikutusta, niin nyt ajankohtaiseksi tutkimuksen aiheeksi on noussut somevaikuttajan ja seuraajan suhde.

Numerossa on mukana sekä filosofis-teoreettisia tekstejä että empirialähtöisiä tutkimuksia, niin elokuva-analyysejä, televisio- kuin sometutkimusta. Teksteissä käsitellään toisaalta tämän hetken ilmiöitä, kuten sosiaalisen median käytäntöjä ja nordic noiria, ja toisaalta paneudutaan median historiaan. Tarjolla on näkökulmia aiheisiin, kuten showpainiin ja itsemurhien elokuvarepresentaatioihin, joista ei ole aiemmin tutkimusta suomeksi juuri julkaistu.

Artikkeleista puolet eli neljä käsittelee elokuvia tai televisiosarjoja. Ilkka Levä kirjoittaa David Fincherin Fight Clubin (1999) metaelokuvallisuudesta ja tarkastelee sen tuottamaa ja kritisoimaa työn kuvaa uusliberalistisen yhteiskunnan kontekstissa Gilles Deleuzen ja Jonathan Bellerin teorioiden kautta. Heidi Kosonen käsittelee elokuvallisen itsemurhan tabuluonteisuutta ja erilaisiin kulttuurisiin konteksteihin sijoittuvia itsemurhia esimerkkinä Ari Asterin kauhuelokuva Midsommar - loputon yö (2019).

Sini Monosen tutkimuskohteena puolestaan on äänen ja musiikin ilmentämät affektit nordic noiria edustavassa suomalaisessa televisiosarjassa Kaikki synnit (ensimmäinen tuotantokausi 2019). Petri Jokinen tarkastelee näkökulma-artikkelissaan Chris Markerin elokuvaa La Jetée (1962) allegoria- 
na postmodernista aikakokemuksesta historiallistavan tulkinnan kautta. Kosonen ja Mononen analysoivat erityisesti kerronnan, representaation ja tyylin ulottuvuuksia, kun taas Levän ja Jokisen artikkeleissa elokuvat toimivat pikemminkin lähtökohtana teoreettisemmalle, representaation tuolle puolen kurottavalle pohdiskelulle.

Faktaa ja fiktiota iloisesti sekoittanut lama-ajan suosikkisarja Frank Pappa Show (1991-1994) on tarkastelun kohteena Noora Kallioniemen ja Sami Hantulan artikkelissa. Frank Pappa uudisti viihteen kenttää rakentaessaan pohjaa nykyiselle ironisia, satiirisia ja parodisia viestejä vilisevälle 2000-luvun mediakulttuurille. Kallioniemi ja Hantula analysoivat tekstissään erityisesti sarjan televisuaalista muotokieltä ja pohtivat, kuinka sarja osallistui politiikasta käytävään julkiseen keskusteluun.

Faktan ja fiktion sekoittaminen on keskeinen osa myös spektaakkelimaista showpaini-viihdettä, jonka narratiivisiin rakenteisiin paneutuu tapausesimerkin avulla Jyrki Korpuan ja Juho Longin tutkimusartikkeli.

Täysin erilaisiin kohtaamisiin vie Miisa Rotola-Pukkilan ja Pekka Isotaluksen artikkeli "Ystävyyttä vai illuusiota?". Se sukeltaa sosiaalisen median arkisiin käytänteisiin ja hyödyntää toisen kirjoittajan ainutlaatuista tutkijapositiota tarkastellessaan parasosiaalisuutta Mmiisas-vaikuttajan ja tämän seuraajien välillä.

Tarjolla on siis sekä lähiluentaan pohjautuvia analyysejä että teosten tulkintaa osana filosofista pohdintaa - ikään kuin laajakuvina. On hienoa ja arvokasta saada julkaista tutkimusta näin moninaisista aiheista suomeksi.

Keväällä käynnistimme toimituskunnassa pitkään hautuneen projektin, jossa kehitetään lehden monikanavaista viestintää vastaamaan tämän päivän tarpeisiin. Kehittämisprojekti on mahdollistanut tiedeviestinnän merkityksen ja tavoitteiden pohtimisen juuri Lähikuvan kontekstissa. Ainoana elokuvan ja audiovisuaalisen kulttuurin tutkimukseen keskittyvänä kokonaan suomenkielisenä tiedelehtenä olemassaolomme rakentaa ja ruokkii paitsi paikallista tutkimusta myös paikallista elävää kulttuuria. Etsimällä uusia viestintäväyliä ja -tapoja pyrimme tavoittamaan entistä laajemmin audiovisuaalisen kulttuurin ystäviä myös akatemian ulkopuolelta. Ruohonjuuritason elokuvakulttuurin vaaliminen ja keskusteluun osallistuminen on osa lehden monipolvista historiaa, sillä Lähikuva aloitti toimintansa Turun elokuvakerhon jäsenlehtenä 1960-luvulla.

Lähikuvan raikastettu visuaalinen ilme rakentuu kerroksellisesti ammentaen lehden pitkistä perinteistä. Vanhan logon rinnalle on uudistuksessa tuotu linssi toistuvana visuaalisena elementtinä. Kameran ja projektorin teknisenä osana linssi yhdistää toisiinsa erilaisia audiovisuaalisen kulttuurin osa-alueita. Symbolina se kuvaa myös tutkimusta tarkasteluna ja läheltä katsomisena. Lopulta linssi paikantuu myös ruumiillisesti osaksi katsomisen prosesseja.

Tämän numeron työstämisen lomassa on jälleen keskusteltu paitsi Lähikuvan toimituksen piirissä myös kansallisella tasolla pienten kotimaisten tiedelehtien vaikeasta tilanteesta ja pohdittu, miten niiden toiminta voitaisiin turvata (eli rahoittaa) avoimen julkaisemisen aikakaudella. On selvää, että yrityksemme ratkaista näitä asioita vuodesta toiseen vaikeuttavat keskittymistä lehden varsinaiseen tehtävään. Toivommekin, että löytäisimme yhteistyössä eri toimijoiden kesken pian ratkaisuja kotimaisten tiedelehtien kimuranttiin tilanteeseen ja voisimme Lähikuvassakin keskittyäjälleen kaikkein tärkeimpään eli laadukkaan lehden toimittamiseen.

Elämme muutenkin vaikeita aikoja kulttuurin ja taiteen elinvoimaisuutta ajatellen. Taiteen ja kulttuurin tekijät ovat joutuneet kärsimään suhteettoman 
paljon pandemiaan liittyvistä rajoituksista. Samaan aikaan taiteiden tutkimuksen piirissä on käynnissä kehityskulku, jossa kokonaisia tutkimusaloja hävitetään, koulutusohjelmia ajetaan alas ja opetusvirkoja jätetään täyttämättä ympäri Suomen.

Tilanteen esiin tuomiseksi ja korjaamiseksi perustettiin huhtikuussa 2021 Taiteidentutkimuksen seurojen neuvottelukunta, jossa myös Lähikuvan taustayhteisö Suomen Elokuvatutkimuksen Seura ry on mukana. Nyt jos koskaan on aika puhua taiteen ja kulttuurin tutkimuksen perusrakenteiden puolesta ja vaalia niitä kaikin mahdollisin tavoin. Jatketaan siis tutkimista, lukemista, kirjoittamista, ajattelemista, keskustelemista ja jakamista!

Jyväskylässä ja Lahdessa 1.9.2021

Kaisa Hiltunen ja Miina Kaartinen

\section{SUOMEN ELOKUVATUTKIMUKSEN SEURAN} SUURI SYYSSEMINAARI 12.11.2021

Suomen Elokuvatutkimuksen Seura järjestää legendaarisen vuosiseminaarin elokuvan ja audiovisuaalisen median tutkijoille Helsingissä Aalto-yliopisto Töölön salissa A305 (Runeberginkatu 14-16, 00100 Helsinki) perjantaina 12.11.2021.

Ohjelmassa on ajankohtaiseen tutkimukseen tutustumista, materiaaliesittelyjä, keskusteluja ja verkostoitumista. Mukaan ovat tervetulleita kaikki elokuvaa, televisiota, pelejä, av-mediaa tai niihin liittyviä aiheita tutkivat ja tutkimuksesta kiinnostuneet - niin graduntekijät, väitöskirjantekijät kuin väitelleetkin!

Osallistujia pyydetään valmistelemaan lyhył esitys (noin $20 \mathrm{~min}$ ) omasta tutkimusaiheestaan. Esitelmien maksimipituus ja aikataulu varmistuvat, kun tiedetään osallistujamäärä. Ilmoittaudu esitelmän pitäjäksi pe 15.10.2021 mennessä osoitteeseen

elokuvatutkimuksen.seura@gmail.com

Ilmoita sähköpostissa nimesi, yhteystietosi, organisaatiosi (esim. yliopisto/ oppiaine) ja esityksesi alustava otsikko.

Tilaisuuteen voi osallistua myös ilman esitystä, ja seminaarin jälkeen pidetään Suomen Elokuvatutkimuksen Seura ry:n syyskokous.

Seminaari pyritään järiestämään hybridimallina niin, että sekä esitelmän pitäjillä että muilla osallistujilla on mahdollisuus osallistua myös etänä.

TERVETULOA MUKAAN SANKOIN JOUKOIN! 